\title{
Tagore's Gora: A Reformist's Protest Against Religious And Social Fundamentalism
}

\author{
Dr. Neelam
}

Pgt English

Ghs Gorchhi

DSE Haryana, India

neelamberwal86@gmail.com

Dr. Devender Singh

Assistant Professor in English

Dept. of LHC, COBS\&H

Chaudhary Charan Singh Haryana Agricultural University

Hisar, Haryana, India

Abstract

In the 19th century, Bengal Hindu orthodoxy and fundamentalism were at their height as seen in the strict observances of the caste distinctions. Women were subjected to inhuman practices like Sati, Purdah, Child marriage, etc. A reform movement was initiated by Raja Ram Mohan Roy through his institution of BrahmoSamaj. Rabindranath Tagore along with his father and grandfather was also an adherent of BrahmoSamaj. His keen desire for an end to bigotry and awakening of reason finds expression in his novel Gora. In fact, Tagore seems to be using the novel to make a fervent appeal against discrimination, orthodoxy and intolerance. He wishes for a country which would be free from injustice and cruelty towards the poor and weak. 
Keywords : Cult of Bhakti, Sati, BrahmoSamaj, Revivalism, Brahminical, Bigotry. Introduction

The Bengal of the nineteenth and early twentieth century was a region undergoing turmoil and turbulences which was not only political but also religious and social. The British East India Company had made Calcutta as the capital of its Indian Empire which brought about great changes in the traditional socio-cultural ethos of the people. Earlier to the British there had been the rule of Muslim Nawabs, who had been overthrown by the former. During the Muslim ruff lasting a few centuries the Hindu populace developed the ethos and habit of being aloof and restrained from outward show and ceremony in matters of religion. The Hindus for fear of repression and punishment became stoical, looking inward into their own selves for spiritual strength and inspiration. The cult of Bhakti, too, which was propagated by Chaitanya and was very popular in Bengal exhorted the people to surrender themselves to faith and to look inward through meditation to achieve purification and salvation. The worship of Durga which was the main focus of religious devotion also emphasised on aloofness or withdrawal from worldliness. The Bengali's gave their taxes and tariffs to the Muslim rulers and remained immersed in their own inner world of religious contemplation and peace. However with the establishment of the rule of the British East India Company the Hindus were shaken out of their stupor and stagnation. The Hindus now were free of the fear of Muslim intolerance and repression. They took to study of western sciences and literature and soon the Indian Renaissance took birth. It was the personage of Ram Mohan Roy who started this intellectual revolution by founding the BrahmoSamaj in 1828. In the very next year he was able to get the practice of Sati or widow burning declared as illegal. It was a turning point in the socio-religious history of the Hindus. 
The BrahmoSamaj comprised of intellectuals and reformists who were aware of the evils which had crept into the Hindu religion and society. As Laxmi Subramanian, the historian states, "Social reform movements led by Ram Mohan Roy and his disciples meant the transformation of individual lives in the direction of rational and humane standards of belief and behaviour." (166) The Tagore was one of the prominent families who took part in this great reformist movement which started in Bengal Prince Dwarkanath the grandfather of Rabindranath Tagore, and his father Devendranath Tagore were ardent zealots of this movement which was against birth based casteism, idol worship, Purdah (practice of keeping women in seclusion), Sati or burning of the widow on the funeral pyre of her dead husband, Polytheism, etc. They also stood for emancipation of women through education and participation in social life. They disseminated their ideas and ideals through magazines, plays, cultural extravaganzas, debate etc. Rabindranath Tagore was brought up in such an environment and atmosphere of social change, religious reform, and recreating of Hindu values and philosophy whereas the Renaissance in Europe consisted of a reawakening of reason or an intellectual focus on the Greek and the Latin cultures and learning in India, this is generally in the context of the awakening of the conscience or social morality of the people. The leaders of this new consciousness had learnt of Humanism and Liberalism from the Europeans and they too desired to bring about social equality, liberty and justice here in India. Much of the Christian religious and ethical values were also appreciated and assimilated by the Bengalis. As Hindus society was totally dominated and regulated by religion, therefore society could only be reformed by reforming religious attitudes and beliefs. Thus, the thrust of the reformers seeking change in society and its values was on reform in religion. The BrahmoSamaji's were not much different from other Hindus as far as language, diet, dress or even most customs were concerned but they did differ on many fundamental religious principles. 
Tagore's Gora not only focuses on the petty narrow orthodoxy of the Bengali Brahmins of the 2 nd half of the 19th century but also makes a strong case for reform and restructuring of contemporary society and the value system. Tagore's Gora relates the story of an English child whose father has been killed in revolt of 1857 and whose mother gives birth to him in the home of a Bengali couple and subsequently dies. The child is nicknamed Gora, as he is very fair complexioned although he is formally called Gour Mohan. The Bengali lady AnandMoyi is childless and decides to keep the child and bring him up even though it is against the prevalent religious / social customs. She has subsequently to undergo a type of ostracism and has to keep aloof from most religious ceremonies and rituals because the Hindu Brahmin community is very strict and rigid about the observances of caste and its obligations. The characters in the story are portrayed realistically with great subtlety and delicacy and an exact picture of social injustice and exploitation is seen and felt. The following lines from Gora show the condition of AnandMoy the foster mother of the protagonist. "Gora", exclaimed AnandMoyi "haven't I been telling you again and again that I severed my connection with my society a long time ago? That is why society hates me so much and why I keep myself aloof from it." (341).

A Hindu lady would not only be ridiculed for having adopted an English child but would also be scorned and despised for being childless. Such customs as are inhuman and illogical are shown as normal and ordinary in the to highlight perverseness and moral decay. The unhealthy link between society and religion is highlighted through the words of PareshBabu, a saintly figure in the novel when he says the social system of our country is intimately bound up with religious opinions - therefore with all our social observances religious practices have some connection (309). The society portrayed is very rigid, 
ritualistic, superstitious, narrow minded and orthodox. Doubtlessly Tagore has through his novel shown the social evils and malpractices as he felt that they were wrong.

The Brahmin lot is completely immersed in thoughts of their own purity, superiority and holiness. They look down on all other human beings as though they could be polluted by even their mere looks. Krishna Dayal the foster father of Gora is a prime example of such bigotry and sanctimony. He never loved Gora and cannot even bear the sight of him in the house and temple as he feels it may get polluted. Whenever there are important religious observances in the house both Gora and his foster mother have to go away somewhere else because their presence is considered inauspicious and undesirable. Krishna Dayal is so rigid and subservient to his Brahminical heritage that he never allows any human feelings or emotions to come into his heart with respect to Gora, his foster child. In the end of the novel he reveals the truth of Gora's ancestry to him because he doesn't want Gora to take part in his funeral obsequies. He considers Gora to be unclean, impure and unworthy because he believes in the birth based caste system. He never feels a father's love for the orphan child who have been brought up in his own house, by his own wife and in the authentic Bengali traditions, so much so that he has even become a Hindu militant and revivalist.

The social condition that is revealed to Gora when he undertakes a tour of rural areas appals and astonishes him. He finds them to be totally divided, narrow and rigid. He is so bewildered that a storm rages in his mind, and he is unable to believe what he has encountered as these lines reveal, "How divided, how narrow, how weak was this expanse of rural india, what guifs of social separation. The most trivial things looked so big to them (132). The social setup is mean and divided into hostile camps on the basis of caste system and the communities are not ready to give any concessions or make any compromises with their social inferiors or superiors. Gora's friends too are always conscious of their Brahminical purity and find it difficult to partake of food, water or shelter with those whom 
they believe to be unclean because of their low caste. The condition of the low caste people who are also the poorest of the lot is very pitiable and they are without any hope of salvation or redemption. They believe what they have been taught to believe, that it is their destiny which has brought them to this pass as also God's will and therefore, it is heresy seek to oppose fate, miserable though it may seem. The novelist Tagore through a third person narration observes in one specific situation, "Rampati tortured with thirst, wondered where he could get any drinking water, fit for a Hindu. There was a small well near the barber's house, but the water polluted by this renegade's touch could not serve for his need. (133). The Brahmins do not only consider lesser Hindus as impure but they include Muslims in the category. The illogical and bigoted mind set which is revealed in the above lines was common to most of the people of those times especially the upper caste and the village folk Water could become polluted by the mere touch of a lower caste person. Gora who had been dreaming of an ideal united India soon realises the stark truth and becomes disillusioned. He realises that the centuries of observance of discriminatory rituals and taboos have created such divisions and schisms between the people that they are virtually impassable. Thus his patriotic vision collapses and he is filled with emptiness and disgust Gora's thoughts run in this direction and vein, "Every person had an absolutely simple faith in social custom-it never occurred to them to question such matters. But this implicit faith in tradition and the bondage of society did not give them the least bit of strength for the tasks of their daily life. It is in fact doubtful whether in the whole world could be found a species of animal so impotent to judge what was for their own good, so helpless and so cowardly- Apart from observing traditional customs their minds were completely unconscious of what was for their welfare and even if it was explained to them they would not understand"(367). 
The rural people who were largely illiterate had been so brain washed by the religious orthodox tradition that they had lost all individuality and reason. They could not even help their own selves. Tagore's deep concern for the pathetic condition of the common man comes out through his description. As an intellectual and humanist he wants these people to be free from the shackles of bigotry and senseless habit. The protagonist Gora is more or less a medium through which Tagore is himself speaking. He voices his love for his country, his concern for its unification and his desire for socio-religious emancipation through this novel. The custom of child marriage as well as that of dowry is revealed in all its baseness and inhumanness. The widow HanMohin's pitiable and horrible condition too is revealed which was the custom of those times. Her married life which starts as a child bride is so inhuman and harsh that it evokes a sense of horror and revulsion in the reader. Her condition goes from bad to worse and finally she is homeless and destitute, her only fault being that she is a victim of fate and a woman in a man-dominated superstitious and repressive society. The irony lies in the fact that she is unable to reason and analyse her situation properly and even tries to put her own niece Sucharta in the same predicament by trying to marry her to a member of the same family who had abused and discarded her.

Tagore's other protagonist apart from Gora is Binoy, Gora's friend. He is a contrast to Gora, a shy, scholarly and emotional orphan. He is a typical young man of those times who is caught between two opposite currents, one of modernity and the other of traditionality. Through him, Tagore shows the need for adaptability and transformation. Binoy changes drastically in the novel, from being a follower and a shadow of Gora he becomes an altogether different personality, having his own individuality and ideals. He lacks the emotional and intellectual depth of Gora but ultimately he finds love in his cheerless existence, by being firm and determined. Though Tagore believes in the superiority of the BrahmoSamaj he does not depict it as completely free of faults. The Brahmos too, have their 
Haran Babus and Mistress Barodas. Ultimately, it seems that it is the humans who make the difference every where; they can distort and twist even the best of things and, conversely brighten and better the worst of conditions. Binoy who has nothing, manages to marry Lolita, through changing his own self, by accommodating himself to her and achieves happiness. Haran who has a high position in the Brahmo society and good prospects loses the love and affection of his would be wife - Sucharita through his bigotry and presumptuousness. The message which Tagore sends out through his good characters is one of humility, humanity, conviction, dedication, love and mutual needs.

Tagore shows the extreme nationalism and Brahminical superiority of the early Gora who has set up a association of youth for preaching fundamentalism. However as Gora gains experience through the rough and tumble of life doubts begin to assail him. He also meets saintly people like Paresh Babu and finally he realizes that Hindu orthodoxy can only serve to chain and imprison his intellectuality and desire for freedom. Gora is shown as a seeker after truth who is restless, energetic and a zealot. He is an intense, impassioned and inspired young man who finally is able to break free of the rigidity and bigotry of Brahminism when the secret of his birth is revealed to him. An irony which is presented by Tagore is that Gora who is an Englishman by birth is the most devoted to the cause of Brahminical purity and independence of the country, this conviction is found lacking in those who are authentic Brahmins and Indians. This fact seems to point towards a basic weakness and flaw in the philosophy and structure of Brahminical Hinduism. The actors in novel are basically mouthpieces who voice Tagore's concern especially people like Paresh Babu and the later enlightened Gora. The incidents too are knit together to formulate and portray Tagore's socioreligious concerns which are basically for reform of Hindu religion with all its paraphernalia of Caste, Patriarchy, ritualístic Orthodoxy and bigotry. The unjust imprisonment of Gora also exposes the highhandedness of the British who are basically there as rulers, because, of the 
weakness and disunity of the Indians. Gora is even a precursor of Mahatma Gandhi as he voluntarily goes to jail without defending himself - on a sort of Satyagraha. Tagore's family were all immersed in, and dedicated, to socio-religious reform and this novel comes out as a powerful protest against the evils of those days.

Thus the basic desire of Tagore as revealed in Gora is for freedom and emancipation from bigotry exploitation and ignorance. This novel is the medium through which Tagore's vision for the future is revealed. 


\section{References}

Subramanian, Lakshmi. History of India, 1707-1857. Hyderabad: Orient Blackswan Private Limited. 2010. rpt 2012, 2016, 2017, 2018 Print.

Tagore, RabindraNath. Gora London MacMillan and Co. Ltd. 1963. Print. Tagore, RabindraNath. Sounds of Stillness. Ed. Surender Singh Sangwan. New Delhi: Oxford U.P., 2005. Seventh Impression, 2010. Print. 